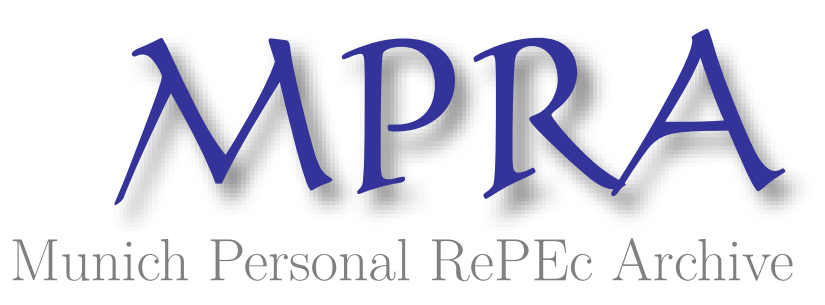

\title{
INSURANCE INDUSTRY IN ERITREA - ACHIEVEMENTS AND CHALLENGES
}

Rena, Ravinder

Department of Business and Economics, Eritrea Institute of Technology, Mai Nefhi, Asmara, The State of Eritrea

February 2007

Online at https://mpra.ub.uni-muenchen.de/10762/

MPRA Paper No. 10762, posted 27 Sep 2008 23:50 UTC 


\title{
INSURANCE INDUSTRY IN ERITREA - ACHIEVEMENTS AND CHALLENGES
}

\author{
Ravinder Rena*
}

\begin{abstract}
The industrial revolution led to the birth of different types of insurance systems. Insurance business emerged and developed in Eritrea during the Italian period. The insurance industry in Eritrea has been huge profits from its inception in 1992. In spite of the consistent profits by the insurance, the Government privatised it recently due the policy and revenue requirements. An attempt is made in this paper to discuss the background of the insurance and it evolution and development. This paper focuses on achievements and challenges of Eritrean insurance industry after independence. The paper attempts to synthesise diverse viewpoints, protect confidentiality and offer insights into the ever-changing insurance environment in Eritrea.
\end{abstract}

\section{Keywords: Eritrea, Insurance Industry, challenges and achievements, etc.}

\section{INTRODUCTION}

The industrial revolution led to the birth of different types of insurance systems. The employers and employees were exposed to many risks on account of fire, accidents, theft, etc., soon insurance houses were established to meet this need. Thus accident insurance, social insurance, theft insurance, motor vehicle insurance, etc., emerged. Later on, other forms of insurance such as crop insurance, livestock insurance, house insurance etc., came into existence (Levine, 1997; Rena, 2006a). It is evident that man is exposed to risks in all walks of life. Unless he minimizes loss arising from such risks, society will never progress. Insurance comes to his aid in minimizing the loss. Insurance business emerged and developed in Eritrea during the Italian period (Mauri, 2003).

Eritrea gained its independence from Ethiopia on 24 May 1991 after a liberation war that lasted for 30 years and was one of the poorest in the world with both its infrastructure and economy in ruins. It is located in the North Eastern of Africa with a total area of 124,432 $\mathrm{km} 2$, bordered in the north and west by Sudan, in the south by Ethiopia and Djibouti, and in the east by the Red Sea. It has an estimated population of about 4.5 million. Its annual population growth is estimated at 2.9 percent. Eritrea has nine ethnic groups and six administrative zobas (provinces/regions). Its per capita income is USD 230. The

* Department of Business and Economics, Post Box No: 7956, Eritrea Institute of Technology, Mai Nefhi, (under Ministry of Education), Asmara, The State of Eritrea Email: ravinder_rena@yahoo.com , drravinderrena@gmail.com 
Rena, Ravinder (2007) "Insurance industry in Eritrea - Achievements and Challenges", Hyderabad (India): Osmania Journal of International Business Studies (ISSN: 00973-5372), (January-June), Vol.2. No.1. pp.140-146.

government has been pursuing policies and investments that promoted rapid and equitable economic growth during 1994-1997. However, a border conflict with Ethiopia started in May 1998 and degenerated into a full-scale war that resulted in loss of human life, damage to physical infrastructure, and the displacement of nearly one-third of the total population (Rena, 2005; Rena,2006b).

Following the signing of the Algiers peace agreement in December 2000, the deployment of the UN mission for Ethiopia and Eritrea (UNMEE) and the establishment of a 25-km. temporary security zone along the entire 1,000-km. border between Eritrea and Ethiopia, the Border Commission finally delivered its verdict on the border dispute between the two countries in April 2002. Eritrea can now focus on the many post-war recovery challenges, among them the need to rehabilitate and reconstruct the damaged social and economic infrastructure in the war affected regions; assisting the remaining 70,000 internally displaced persons (IDPs) return to their homes and restoring their means of livelihoods; reintegrating 180,000 refugees from the Sudan, Djibouti and Yemen and the 75,000 expellees from Ethiopia (Rena, 2006b). In this context Insurance Industry in the country gained greater significance. This paper provides an overview of only insurance company(NICE) in the country. It also highlights the achievements and challenges that are faced for the last 16 years of independence.

The major limitation of this paper is the problem of getting data for a relatively long period of time. The data for Eritrea includes only the past 14 years since there was no separate data for Eritrea before its independence from Ethiopia. In addition, existing data is not always reliable and it may not be precise and suitable for the question at hand. Moreover, the limited amount of empirical studies on the insurance industry in the country also limits the study.

\section{BACKGROUND OF THE INSURANCE INDUSTRY}

The Government of Eritrea enacted a Proclamation No. 20/1992 for the establishment of the Insurance Corporation on 1 May 1992, which provided the Corporation to enjoy a monopolistic power in the market. The National Insurance Corporation of Eritrea (NICE) was formed as an autonomous public enterprise transacting all classes of insurance business. The Initial capital of the NICE was 5,000,000. This was subsequently increased Nakfa 52,338,000 in 2004. It is to be noted that NICE has full-fledged insurance facilities and provides different types of insurance services required by individuals and companies. The NICE is a corporate company, which deals both life and non-life risks. It is reported that majority of its revenue stem from non-life underwriting with motor insurance playing a dominant role. The Corporation's business is restricted to within Eritrea and operates out of three locations: Asmara (headquarters), Massawa and Assab. The Corporation markets its products through its internal marketing department as well as utilizing network of agents. The NICE currently underwrites life and non-life classes of insurance including: Motor, Fire, Accident, Livestock, Engineering, Marine, and Aviation (Rena, 2006a). 
Rena, Ravinder (2007) "Insurance industry in Eritrea - Achievements and Challenges", Hyderabad (India): Osmania Journal of International Business Studies (ISSN: 00973-5372), (January-June), Vol.2. No.1. pp.140-146.

Growth and Development: In line with its transitional economic development and poverty reduction strategies, the Government of Eritrea decided to privatize the NICE: to 1] Attract private sector investment; 2] Privatize Government-owned enterprise; and 3] Develop a sound financial system.

The Government is encouraging the private sector to lead economic development and growth through the increased investment. The Privatization of the NICE indicates the Government's largest privatization program to date. The privatization program has been finalized and it is reported that around 1,700 Eritreans have invested and thus become new members of the Corporation. In 2004; Eritreans around the world expressed an interest in buying NICE shares. All in all, around 750 Eritreans at home, and more than 1,000 abroad have bought NICE shares. Other shares are owned by the Martyrs' Trust Fund, with the remaining shares still retained by the Government. With the transfer of shares to the public, NICE is now looking for ways to establish an Over-The-Counter (OTC) market for the trading of its shares. Owing to its skilled and prudent financial as well as operational management, NICE has shown remarkable growth since its establishment in 1991. The Corporation's gross profits have risen from a mere 4 million Nakfa in 1992 to about 60 million Nakfa in 2004 (Rena, 2006a).

The Corporation is heavily reliant on motor insurance policies with over 48 per cent of Gross Premiums in 2004 being either from comprehensive or third party motor coverage. The second largest business class in 2004 was fire and accident at 20 per cent of the total value of the Gross Premiums. A history of the breakdown of the Gross Premiums per business class volume is explained in table- 1.1 .

Table- 1 Gross Premium of the NICE During the Period 1992-2004 (Value in '000 Nakfa)

\begin{tabular}{|l|l|l|l|l|l|}
\hline Type of business / year & Motor & Fire and Accident & Marine and Aviation & Life & Total \\
\hline 1992 & 7,717 & 5,992 & 3,706 & 35 & 17,450 \\
\hline 1993 & 12,565 & 5,153 & 8,252 & 100 & 26,070 \\
\hline 1994 & 14,233 & 7,955 & 9,647 & 282 & 32,117 \\
\hline 1995 & 26,988 & 10,706 & 12,921 & 367 & 50,982 \\
\hline 1996 & 35,106 & 16,989 & 14,117 & 1,488 & 67,604 \\
\hline 1997 & 35,687 & 18,245 & 14,021 & 2,136 & 70,089 \\
\hline 1998 & 38,475 & 15,584 & 14,253 & 2,483 & 70,795 \\
\hline 1999 & 42,500 & 17,593 & 12,033 & 2,413 & 74,539 \\
\hline 2000 & 44,950 & 16,820 & 12,463 & 2,268 & 76,501 \\
\hline 2001 & 51,543 & 21,351 & 15,238 & 2,212 & 90,344 \\
\hline 2002 & 64,272 & 26,331 & 18,700 & 1,840 & 111,143 \\
\hline 2003 & 66,589 & 27,921 & 27,700 & 2,021 & 124,231 \\
\hline 2004 & 72,138 & 30,158 & 47,059 & 2,433 & 151,788 \\
\hline
\end{tabular}

Source: NICE- Records

\section{Objectives}

The Corporation has the following objectives as stated in Article 5 of the Proclamation:

1) Engage in all classes of insurance business. 
Rena, Ravinder (2007) "Insurance industry in Eritrea - Achievements and Challenges", Hyderabad (India): Osmania Journal of International Business Studies (ISSN: 00973-5372), (January-June), Vol.2. No.1. pp.140-146.

2) Guarantee that the population understands the benefits of insurance and that insurance serviced are made available to the public.

3) Enhance efficient utilization of both materials and financial insurance resource.

\section{Safety Measures}

The National Insurance Corporation of Eritrea applies the following measures to treat catastrophic losses.

1. NICE has reinsurance agreements with overseas reinsurers.

2. It allocated 10 per cent of its profit for technical reserve to cover catastrophic claims.

3. It keeps aside 10 per cent of its net profit to the "general reserve.

\section{The Board of Directors and Alternate Directors}

It is to be noted that the Ministry of Finance and the Martyrs' Trust Fund are the biggest shareholders with 64 and 30 per cent respectively. The Board of Directors consisting of seven shareholders with the Ministry of Finance as its chairmen. The Board of Directors in accordance to Article 11 (i) and (ii) of the Memorandum of Association can appoint their representatives in case of their absence.

A) The Board of Directors shall consist of seven members.

B)The election procedure of he Board of Directors shall be as follows:

i] The Ministry of Finance is entitled to nominate and appoint two Directors; ii] The Ministry of Labour \& Human Welfare (Martyrs' Trust Fund) is entitled to nominate and appoint one Director; iii] The other share holders are entitled to nominate and appoint four Directors.

C) In order to be elected as member of the Board of Directors, a person should have the relevant educational back ground and/or the professional qualification and experience that can enable him to productively contribute to the Company.

D) The term of each member of the Board of Directors shall be 3 years. Directors may be re-elected at the expiration of their terms.

E) The members of the Board shall elect Chairman from among themselves.

F) In accordance with the provision of Article 358 of the Transitional Commercial Code, as soon as the Chairman is elected each Director shall appoint his alternate Director to act for him at any Board meeting that he is unable to attend.

G) The General Manager /Chief Executive Officer/ shall attend Board Meetings having no voting right.

H) The Board shall appoint its Secretary.

The Main features of NICE are: 1] NICE started its business with a paid up capital of Nakfa 5,000,000.00 (five million); 2] NICE is a member of the African Insurance Organization (AIO), Federation of Afro-Asian Insurers and Reinsurers (FAIR) and; 3] NICE has business relationships with overseas reinsurance company.

\section{Organizational structure}

The NICE has recently changed the organizational structure to reflect the new line of business for the management of pensions. The finance department has been separated 
Rena, Ravinder (2007) "Insurance industry in Eritrea - Achievements and Challenges", Hyderabad (India): Osmania Journal of International Business Studies (ISSN: 00973-5372), (January-June), Vol.2. No.1. pp.140-146.

from administration to further strengthen its role to include the investment portfolio management for pensions.

At the top of the organizational structure the Board of Directors is placed. The board has its own secretary who is not a member of the Boards of Directors and the Board performs some principal functions specified by the Proclamation, under the Board of Directors the General Manger is positioned. In the management team, General Manger nominated by the board of directors is at the top. The General Manger is the chief executive officer of the Corporation and has different department mangers under him. Despite an acute labour shortage in the country, NICE has been able to obtain and retain qualified staff members. Almost 50 per cent of the staff has participated in post high school education programs (i.e. university degrees, diplomas and certificates). Twenty-one of the employees have insurance specific qualifications. The NICE encourages its staff to participate in the insurance qualifications program. The Corporation as on 30th November 2005 has 104 employees (including the new pension department) mostly employed at the head quarters in Asmara. Four employees are working in Massawa, six in the Assab branch and ten are in pension department. The employees at 3 branches (including head office) and pension are presented in the table -2 .

Table - 2 Manpower of the NICE by Location as at 30 September 2006.

\begin{tabular}{|l|l|l|l|}
\hline Location & Permanent & Temporary & Total \\
\hline Head Office- Asmara & 81 & 3 & 84 \\
\hline Massawa Branch & 3 & 1 & 4 \\
\hline Assab Branch & 5 & 1 & 6 \\
\hline Pension & 10 & - & 10 \\
\hline Total & 99 & 5 & 104 \\
\hline
\end{tabular}

Source: NICE- Records

\section{IMPORTANT ACHIEVEMENTS}

The NICE has been profitable from inception registering a net profit of Nakfa 2,663,966 in the first full year of operation with a subsequent net profit of Nakfa 39,182,976 in 2004. Further, the liquid assets of the Corporation are either held in bank accounts (Nakfa $77,074,020$ ) as at 31 st December 2004 or invested in government Treasury Bills (Nakfa $30,000,000)$ at current market rates. The Corporation is restricted in its ability to efficiently manage its liquid assets due to the limited availability of investment vehicles in Eritrea as the financial markets are not well developed relative to other countries. As a result, unlike other insurance companies, investment returns do not significantly contribute to profitability.

Computer systems at the headquarters are currently being integrated. However, the branches and the agency network are not online with the Head office. Financial reporting is currently still manual in some areas. With the introduction of the AIO and the Microsoft dynamics software packages in the beginning of 2004, this weakness is currently being addressed. 
Rena, Ravinder (2007) "Insurance industry in Eritrea - Achievements and Challenges", Hyderabad (India): Osmania Journal of International Business Studies (ISSN: 00973-5372), (January-June), Vol.2. No.1. pp.140-146.

The Corporation is planned towards upgrading the knowledge and qualification of its employees. Based on this plan a number of insurance staff involved in Charter Insurance Institute Policies and overseas training and added the Corporation to grow and shall achieve to market services and produces to Eritrean public. The management has also realized the weightings of the Corporation in providing insurance services to the rural population.

\section{IMPORTANT CHALLENGES}

The Eritrean insurance industry has been facing many challenges, most of them common to the financial institutions, which hinders the development of insurance businesses within and outside of Eritrea. Some of the challenges are enlisted below.

1 Lack of Qualified and experienced manpower: All most all the financial institutions, particularly insurance in Eritrea were facing acute shortage of qualified and experienced staff. It is to be noted that insurance is not even taught as a subject in Eritrean schools and higher institutions. Furthermore, the insurance industry is too small to attract many individuals to consider working in the field of insurance. Even after 14 years of independence, it remained as a serious problem (Zeru, 1999).

2 Insurance Legislation: There is no legislation pertaining to the conducting of insurance business in Eritrea. Since insurance is a specialized field and cannot be governed by the general law of contracts. The NICE is imposing many terms and conditions which may not safeguard the interest of the insuring public.

3 Supervisory Authority: The Bank of Eritrea is a controlling and supervisory authority of the financial institutions. But the proper supervision has not yet started on the insurance industry. It is important that the insurers closely supervised in their operation and the industry must be harmonized to play a proper role in providing insurance services to the Eritrean public.

4 Awareness of the Public: It is important to note that majority of Eritrean population is not aware of insurance and its usefulness. The public is not aware of the benefits of insurance and the industry has failed in its endeavours to penetrate in the rural areas of Eritrea where more than 75 per cent of the people live in. Further, insurance contracts are drafted in foreign languages and they are extremely difficult to understand the terms and conditions of the various insurance policies (Rena, 2006a).

5 Biases against Insurance: Insurance products are intangible. The contract of insurance provides a promise to the insured to be indemnified on the happening of a fortuitous event. In the absence of a fortuitous event the insurance company retains the amount paid by the insured. In reality there are only a few people who will face a fortuitous event, the remaining majority will tend to believe that the money paid to the insurance companies have been retained for nothing. It is too abstract for most people to label a price on a product called "peace of mind". 
Secondly, the family and social structure in Eritrea tends to make the need for insurance cover unnecessary. This concept is not unique to Eritrea; it is true in most of the African societies. The family neighbours and friends extend help whenever someone faces a financial problem. Social and religion based associations come to the help of a member whenever a misfortune happens. These cultural insurers have been conducting the financial help for many years and have still maintained in the Eritrean society. It may be argued on whether they are competitors or collaborators, but as an alternative market to the Eritrean insurance industry, thus, they have biases against conventional insurance companies.

6 Irrelevancy of Insurance Products: Insurance products are not designed to reflect the requirement of customers and besides, different terms in the contract of insurance that are not relevant to Eritrean environment. Since most of the insurance services are designed for urban dwellers, the majority of Eritrean population has little access to the benefits of insurance (Zeru, 1999).

7 Border conflict and other Factors: Due to the war with Ethiopia between 1998 and 2000, the promising economic growth was significantly disrupted. Besides, thousands of deaths, the war led to displacement of about one third of the Eritrean population and a major damage to country's infrastructure. As a result, the economic gains of Eritrea during 1991-1997 were reversed. In view of this, at present, Eritrea faces the challenges of reconstructing the infrastructure, assisting the displaced citizens resume their economic activities and reintegrating refugees, rebuilding the economy, restoring social services. Post conflict constraints that continue to affect Eritrea's socio-economic development include: human resource deficiency, a financial and foreign exchange gap, inadequate physical infrastructure, substandard institutional capacity etc. It also faces the challenge of planning and implementing medium-to-long term development programs to achieve rapid economic growth and the reduction of poverty in an environmentally sound manner (Rena, 2006b).

\section{CONCLUSION}

The most important factor in the development of the insurance market in Eritrea is client relationship management. This was closely followed by further regulation and the emerging previously uninsured market. It is hoped that the emerging middle class will provide healthy growth to the industry and spur the growth of the agents. Technology heads up a second less important group which also includes new competition and market capacity in Eritrea.

In addition to the general economic challenges, the trading environment locally, regionally, and internationally was not conducive for the insurance industry in Eritrea particularly after the border conflict with Ethiopia. After the International Court decision on 13th April 2002, the demarcation process not been completed. On the top of that, "nowar no-peace" scenario has deteriorated the economic development of the country and 
Rena, Ravinder (2007) "Insurance industry in Eritrea - Achievements and Challenges", Hyderabad (India): Osmania Journal of International Business Studies (ISSN: 00973-5372), (January-June), Vol.2. No.1. pp.140-146.

has directly affected the growth of insurance business in Eritrea. Besides, the impact of political instability in the Middle East ad the Persian Gulf region, the sudden hike in oil price in 2005, compounded with unprecedented natural hazards, such as the Afro-Asian tsunami end of 2004, Katrina disaster in America (mid 2005) have a negative impact of the insurance industry. Further, September 2001 terrorist attack in America continues to influence the rating of Eritrean reinsurance cost in the international market. Despite the numerous challenges encountered in its trading environment, the NICE has been showing satisfactory performance in terms of profit and premium income and it is considered as one of the profitable insurance company in Africa.

\section{REFERENCES}

Levine, R., 1997, "Financial Development and Economic Growth: Views and Agenda", Journal of Economic Literature 35 (2), pp.688-727.

Mauri, Arnaldo (2003) Eritrea's Early Stages In Monetary And Banking Development. Working Paper no. 28. - Dipartimento di Economia Politica e Aziendale, Università degli Studi di Milano Ottobre, Italy.

Rena, Ravinder (2005) Challenges for Food Security in Eritrea: A Descriptive and Qualitative Analysis. African Development Review; 17(2) 193-212.

Rena, Ravinder (2006a) Financial Institutions in Eritrea, Dar Es Salaam (Tanzania): New Africa Press.

Rena, Ravinder (2006b) A Handbook on the Eritrean Economy: Problems and Prospects for Development. Daar Es Salaam (Tanzania): New Africa Press.

Zeru Woldemichael (1999) "Problems and Prospects of Insurance Industry in Eritrea," a Paper presented in the National Workshop on Development of Finance, Banking and Insurance in Eritrea held at Tiramni (Eritrea) on 7th and 8th May 1999.

$* * * * *$ 